\title{
Interrelationship of Capitalisation, Market Power and Profitability in Selected Food and Beverages Firms in Nigeria
}

\author{
Adekunle R. Onaolapo' ${ }^{1}$, Elijah Adeyinka Adedeji ${ }^{2}$ \\ ${ }^{1 \& 2}$ Ladoke Akintola University of Technology, Ogbomoso. Oyo State. Nigeria
}

\begin{abstract}
This study evaluated the interrelationship of capitalisation, market power and profitability in Food and Beverages Firms in Nigeria. Specifically, the relationship between capitalisation and market power, profitability and market power, also capitalisation and profitability were assessed.

Six companies were purposively selected from Food and Beverages Firms, three from the Food firms and three from the Beverages firms to meet the needs of this panel study. Data for the study were collected using secondary sources within the period of ten years (2001-2010). The interrelationships between capitalisation, market power and profitability were analysed using Pearson Product Moment Correlation Coefficient (PPMCC) and Panel Data Analysis (PDA).

Findings indicated that there is a positive significant impact of capitalisation on profitability in food firms $(r=0.561, p=0.015)$. Capitalisation has a positive significant effect on market power with $(r=0.678, p=0.001)$ for food firms, and $(r=0.932, p=$ 0.001 ) for beverages firms respectively. In addition, a positive relationship was also found to exist between capitalisation size and corporate profitability as $(r=0.885, p=$ 0.000 ) for food firms, and ( $r=0.643, p=0.000)$ for beverages firms.

Based on these findings, the study concluded that there exists a positive and significant interrelationship between capitalisation, market power and profitability of the sampled firms. The study therefore recommended that management must see to an increase in total asset and total equity that will lead to an increase in market share and providing positive return on equity for their firms.
\end{abstract}

Keywords: Capitalisation, Market Power, Profitability, Management, Firms.

\section{INTRODUCTION}

Managers are faced with many different choices every day. In today's competitive world, there is growing pressure to make the right decisions quickly on how to increase business profits. In order to do this, managers need to understand the factors that increase profitability. Previous studies have linked corporate survival to capitalisation, market power and profitability (Buzzel, Gale and Sultan 2000; Rumelt 1998; McGahan and Porter 2001). According to the Boston Consulting Group (BCG) matrix; businesses named stars, are those in rapidly growing markets with high market power. These businesses utilize to the best of their ability long-term opportunities while those with low market power and high growth need to increase their market power in order to become stars. Otherwise, the BCG matrix, suggest divesting this business and repositioning their resources more effectively in order to ensure desire goal attainment. (Pearce and Robinson, 2003).

The correlation among capitalisation, market power and profitability according to Woo (2001) has been a subject of debate over the years. It however remains a generalisation which has been over-extended and accepted without acknowledgement of all its attributes. It was noted that, close association exists among capitalisation, market power and profitability by now, strongly acknowledged by many managers and management scholars as a basic premise of 
business strategy and that market power does not always translate into profitability, as evidenced by a sizable 41 market leaders all earning a pre-tax Return on Investment (ROI) of less than 10\% (Szymanski, 1993).

\section{STATEMENT OF THE PROBLEM}

The above background therefore emphasize among other objectives evaluate whether being a market leader increases a company's ability to earn greater profits. More specifically, it further sought to establish whether the relationship is negative or positive. A number of international studies have been conducted on the same topic using a number of different profitability measures. The extent to which capitalization is linked to profitability has been exhaustively discussed in many literatures focusing on the corporate environment of developed nations Rumelt (1991). Most of these studies are based in such advanced economies as the USA, Australia very little research has been conducted locally owing to a lack of market power information in Nigeria. The beverages firms which occupies a significant position in the Nigeria beverages firms is largely oligopolistic in nature: where market leaders determine the pace of development .The extent to which such market power is linked to capitalisation and targeted profitable performance has not been given much attention in the academic literature. Given the high cost and high risk associated with market share building, it is necessary that Nigerian managers have clearer evidences of the benefits and chances of success before committing scarce corporate resources to market building and profitability planning. In particular, this study attempts to examine the linkage between capitalisation, market power and profitability among selected Food and Beverages Firms in Nigeria within the period of ten years (20012010). On the basis of the linkage between capitalisation and profitability, the study further attempts to undertake an assessment of resource usage among the target study group. The study will provide avenue to further research into the topic of interrelationship of capitalisation, market power, and profitability in selected food and beverages firms in Nigeria. It will also assist in bridging the knowledge gap that exists on the subject locally. It will assist managers in decision-making by using empirical evidence on whether or not a pursuit of market power in order to increase profits works or not.

In the case of strategic decision-making, top management will find this study useful in reviewing strategies for survival and sustainability of their industries. The relevant discourse of the study therefore raised a question as to whether companies with greater market control correspondingly influencing corporate profitability in the industry. Based on this and other relevant issues, the following research questions and objectives were raised.

\section{AIMS AND OBJECTIVES}

The general aim of the study is to evaluate the significance of market power as an influencing factor on corporate performance in the sampled Nigerian industry. The study put forward among other discuss whether selected Nigerian brewery and food firms with greater market control correspondingly possess greater performance metrics. On the basis of these and other relevant issues, the following research questions and study hypothesis are tentatively postulated.

\section{Research Questions}

- Is there any significant interrelationship among capitalisation, market power and profitability?

- Does company growing market power correspondingly influence corporate profitability?

- To what extent does capitalization determine change in corporate profitability for selected firms in the study? 


\section{RESEARCH HYPOTHESES}

Ho1: There is no significant relationship between capitalisation and market power among the sampled firms.

Ho2: Market power has no significant effect on corporate profitability.

Ho3: Capitalisation has no significant influence on corporate profitability.

\section{LITERATURE REVIEW}

The basic framework discussed focus on market power, capitalization and corporate profitability. Emphasis is placed on theory of capitalisation, market power, profitability, metaanalysis theory and theory of assessment as well as efficiency theory. Market power and profitability can be explained as market power advantages. Market power is present when a firm is able to raise its prices or offer inferior products because it rivals are not able to offer customers a reasonable alternative. One can conclude that market power would enable a company to make higher profits as they are able to charge a premium for their products; Jacobson (2000).

Market Power is the ability of a firm to profitability raise the market price of a good or service over marginal cost. In perfectly competitive markets, market participants have no market power. A firm with market power can raise prices without losing customers to competitors. Market participants that have market power are therefore sometimes referred to as 'Price Makers', while those without are sometimes called 'Price Takers'. A firm with market power has the ability to individually affect either the total quantity or the prevailing price in the market. Price makers face a downward - sloping demand curve, such that price increases lead to a lower quantity demanded. The decrease in supply as a result of the exercise of market power creates an economic deadweight loss which is often viewed as socially undesirable. As a result, many countries have anti-trust or other legislation intended to limit the ability of firms to accrue market power. Such legislation often regulates mergers and sometimes introduces a judicial power to compel divestiture; Vatiero (2009). The following two theories of capitalisation are generally employed in order to determine the capital requirements of newly promoted company:

\section{Theory of Cost of Capitalisation:}

The proponents of this theory are, Akintoye (2008) and Boodho (2009). The theory emphased that amount of capitalisation is equal to the total cost incurred in setting up of a corporation as a going concern. This estimation of capital requirements of a newly promoted company is based on the total initial outlays for setting up of a business enterprise. Also, the amount of capitalisation of a company is determined by aggregating: The cost of fixed assets, such as land and building, plant and machinery, goodwill patents, furniture and fixture, etc. The amount of regular working capital required to carry on business operation. The expenses of promotion. The cost of establishing the business.

The original outlays on all these items form the basis for determining the amount of capitalisation. This theory is suitable for determining the amount of capitalisation of a newly promoted corporation. It enables the promoter to know the total initial amount of capital which they should raise. The cost theory of capitalisation is useful for these enterprises in which the amount of fixed capital is more and whose earnings are regular, such as construction and public utility institutions. However, this theory suffers from the basic drawback that the amount of capitalisation is judged by a figure based on the cost of establishing and starting a business and not but its earning. In fact, the amount of business and not by what a firm earns and not capitalisation is determined by what has been invested in it. This does not explain whether the capital invested in a business is justified by ties earnings. The cost basis of 
capitalisation is not satisfactory in the case of a growing concern whose earnings keep on changing whereas the amount of capitalisation remains constant. Also, it is not useful for those enterprises in which the operating cost is changing, earnings are not regular and certain which carry on their business under competitive conditions.

\section{Earning Theory versus Cost Theory of Capitalisation}

These theories have their limitation. As there is no contradiction between them, both are complementary to each other. However, whereas cost theory of capitalisation is suitable for determining the amount of capitalisation of public utility concerns, the earnings theory of capitalisation constitutes a good basis for existing companies. Cost theory of capitalisation should be applied for determining the amount of capitalisation in case of a newly promoted company, as it will be difficult for it to estimate it future earnings which are quite uncertain. As earnings provide a better basis for capitalisation of an established company, a newly promoted company should switch over to the earning theory of capitalisation in later years. Capitalisation of a newly promoted company based on both of the above theories, would be a fair capitalisation. It would save the company from the disastrous evils of both under and over-capitalisation.

\section{Meta - Analysis Theory}

In statistics, a Meta-analysis refers to methods focused on contrasting and combining results from different studies, in the hope of identifying patterns among study results, sources of disagreement among those results or other interesting relationships that may come to light in the context of multiple studies. In its simplest form, this is normally by identification of a common measure of effect size, of which a weighted average might be the output of a metaanalysis.

Leverty (2001) attributed these different views to the fact that each study has reviews and tested different relationships and none of them has ever tried to replicate the finding of the other. His findings were that there is a correlation between market power and profitability and that market power should be treated as an indicator of performance. He also states that the success of market power requires more fundamentals focus. On the same note, Leverty (2001) states that the option to build market power is available for more than one company and that non-price competition is likely to reduce profits associated with market power.

Figure 2.1: Theoretical Framework for Meta-Analysis

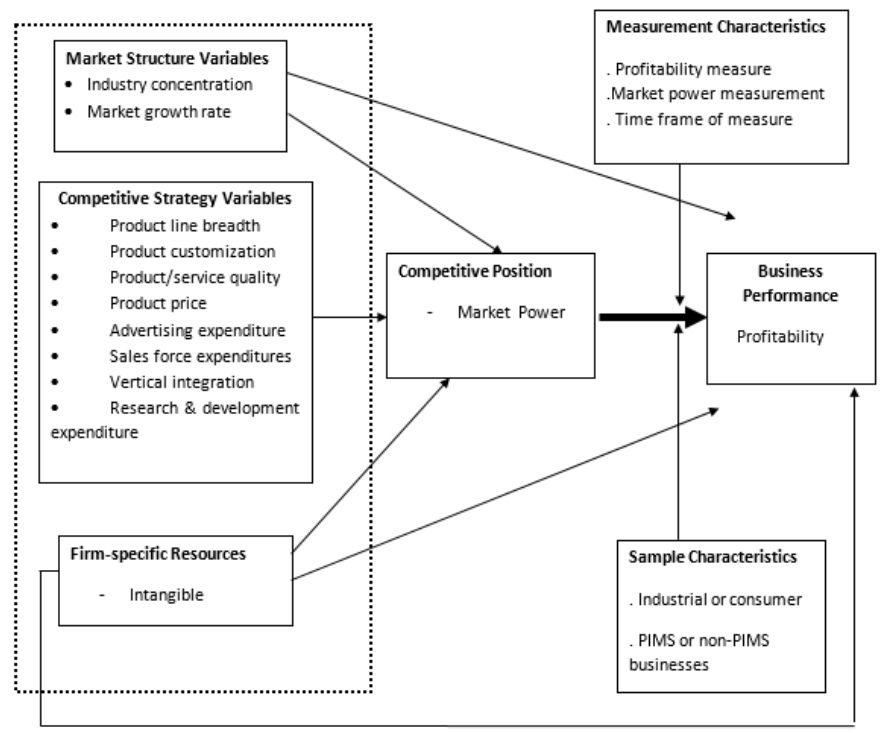

Source: Szymanski, Bharadwaj and Varadarajan(1999) an analysis of the market share-profitability relationship. 
In order to gain competitive position, a company must focus special attention on such variables as market structure variables, competitive strategy and other firm specific resources which have direct influence on market power for business performance.

\section{PROFITABILITY MEASURES}

There are many profitability measures, that can be used, previous studies widely used return on assets (ROA); return on equity (ROE) and the return on invested capital (ROIC) also known as return on investment (ROI), Szymanski (1999) stated that ROI and ROA can be viewed collectively. While these measures of profitability are widely accepted as reliable and strong measures of profitability they have certain shortfalls, most commonly that they are based on accounting information and thus account for neither time value of money nor the investment risks faced by the shareholders. Profitability is measured both for assets valued at cost basis and at market. Note: reference to "Average" is beginning balance + ending balance divided by 2.

- Labour and management earnings equals' net farm income minus an opportunity cost of $6 \%$ on average farm net worth.

- Rate of return on assets is the return to farm assets divided by average farm assets.

- Rate of return on equity is the return on farm equity divided by average farm equity.

- Operating profit margin is the return on farm assets divided by value of farm production.

- Asset turnover rate is the value of farm production divided by average farm assets.

- Interest on farm net worth is the average farm net worth multiplied by a $6 \%$ opportunity interest charge.

- Farm interest expense is the accrued interest cost.

- Value of operator's labour and management is the opportunity cost of the operator investing his or her time and management skills. Each operator makes this estimate which is then multiplied by the number of operators per farm.

- Return on farm assets is calculated by adding farm interest expense and net farm income then subtracting the value of operator's labour and management.

- Return to farm equity is calculated by subtracting the value of operator's labour and management from net farm income.

- Value of farm production is gross farm income minus feeder livestock purchased and adjusted for inventory changes in crops, market livestock and breeding livestock.

\section{Return on Assets}

Rothschild (2006), stated that perhaps the most critical financial goal of manufacturing firms is ROA. Investors rate the management performance of Chief Executive Officers (CEOs) and chief Financial Officers (CFOs) of manufacturing firms largely by their ability to wring profits from the assets under their control. As such, ROA is perhaps the premier metric of quarterly and annual results. However, virtually no company is able to measure and report on ROA at transactional level to allow managers to know ROA impacts on their day -to-day, deal-by-deal choices. The implications of this is that ROA is nothing more than high level after the effect report card on CFOs and CEOs reveal that there is no link between the day to day operations and the key financial goals of manufacturing firms. 
Rothchild (2006) shows the ROA equation as follows:

$$
\text { ROA = Margin X Velocity }
$$

where,

Margin $=\frac{\text { Profit and Velocity }=\frac{\text { Sales Revenue }}{\text { Sales }}}{\text { Assets }}$

The equation suggest that maximising a company's ROA requires managers to understand in great detail the trade-offs between margin and velocity product by product, order by order and customer by customer. In agreement with Rothschild(2006) is selling and Stickney (1998) who see ROA as a measure of a firms' success in using assets to generate profit it without looking at how the assets were financed.

Selling and Stickney (1998) show the ROA equation as follow:

$$
\mathrm{ROA}=\text { Profit Margin X Assets Turnover }
$$

where,

Profit Margin $=$ Net income $+(1-$ Tax rate $)($ interest expense $)$

Revenues

\section{MARKET POWER AND PROFITABILITY}

Earlier studies found that the largest portion of variances in the business unit performance was explained by business unit effects, followed by industry effects and then corporate effects; Rumelts(1998), McGahan and Porter(2001). There are many competing views about the relationship between market power and profitability, most of which have never been reconciled. Base on the studies available the author has chosen to concentrate on three studies as well as three contradictory studies. The study of the relationship between market power and profitability can be traced back to; Buzzel, Gale and Sultan (2000) who reported a positive relationship between the two. They found that higher market power leads to greater profits, because of market power and lower cost resulting to economies of scale effects and also the learning effects. Since then there has been many competing ideas about the relationship between market power and profitability. There are a number of reasons why some authors believe that market profitability could be positively related to market power. Newton (1999) states that if we ignore the possibility of coincidence, the correlation between market power and profitability can be interpreted as follows:

- Market power determines profitability;

- Profitability determines market power;

- Or some other variables determine both market power and profitability which can be interpreted as well managed and successful firms enjoy high profitability and natural growth.

Venkatraman \& Prescott (1996) also found that there was a positive and significant relationship between market power and profitability and that the positive relationship is not the same across different environmental contexts. However, he insists that the correlation between market power and profitability is meaningless unless related to an environmental context, the strategies pursues as well as particular macroeconomic conditions. This is in agreement with; Shanklin(1999) who also concluded that there is a strong link between market power and profitability but also warned against blindly following a market penetration strategy as a company's market power strategy needs to flow from corporate objectives. On the other side, there are those authors who are not convinced by the preceding arguments; Jacobson (2000) found no relationship between market power were due to lack of control of extraneous variance. He argued that the dominant explanation of market power and profitability relationship ignores factors such as management skills, company culture, access to 
scarce resources and luck. Jacobson (2000) also argued that 'strategic intentions' such as investing to expand market share cannot results in abnormal profits under equilibrium because companies will continue to invest until the return premium diminishes. O'Regan (2002) stated that although it is not possible to accept or reject the contention that market power is a driver of performance, it was clear that the market power is an important consideration and one of the main strategic objectives of many companies.

Hegert (1990) reported a non-linear relationship between market power and profitability: the higher the market power, the more profitable the company, up to a point. Firms with a market power of more than $58 \%$ were actually less profitable than those with lower market power. Hegert(1990) found that although the relationship between return on assets and market power was positive in about a third of the industries studied, it was not significant. For almost another third of the industries the relationship was negative. He concluded that the alleged association between market power and profitability is not strong enough to warrant strategic marketing and management decisions to press for market leadership. Haggie et al (1999) suggested that 'it is a long standing view that market power and profitability cannot be pursued in tandem'. This will seem true because an increase in market power mostly requires more investment which might diminish the profitability in the short term. However, this seems to suggest that for a company to pursuit market power they will have to forgo some profits. This literature, therefore suggest an inverse relationship in the initial phase. Fraeing and Minor (2004) summarised previous studies on the topic and the results reflect the fact that there is no agreement on whether a relationship exists between market power and profitability.

\section{MATERIALS AND METHODS}

The area for the study is the selected food and beverages firms in Nigeria with greater emphasis on the selected firms which are: Nestle Nigeria Plc. with Head office located in Ogun State; Cadbury Nigeria Plc. with Head office located in Agbara, Ogun State; Flour Mills Nigeria Plc. with Head office located in Apapa, Lagos State; Guinness Nigeria Plc. with Head office located in Lagos State; Nigerian Breweries Plc. with Head office located in Ibadan, Oyo State; and, International Brewery Plc. with Head office located in Ilesha, Osun State. The study examined interrelationship of selected firms' capitalisation, market power and profitability within the study period. The focus of this work is on these operational parameters as justification for rising capitalisation in the study area within the study period.

Descriptive statistics were employed to describe the interrelationship of capitalization, market power and profitability using tables, ratios and percentages to measure each of the variables, while formulated hypotheses were tested using inferential statistical techniques.

The relationships between variables were determined using the Pearson Product Moment Correlation Coefficient (PPMCC) and Panel Data Analysis that involved the use of both the fixed and random effects analysis.

\section{RESULTS AND DISCUSSION}

Three hypotheses earlier stated in chapter one are tested using Pearson Moment Correlation Coefficient and Panel Data Analysis through STATA 10 package.

\section{Hypothesis One:}

H0: There is no significant relationship between capitalisation and market power among the sampled firms.

Table 4.1 shows the relationship between capitalisation and market power of both food and beverages firms. The variables involved are market share, total assets and total equity. It also 
revealed that both total asset and total equity have positive correlation of 0.369 and 0.519 respectively with market share for food firms. This is also seen to be significant at $5 \%$. This shows that an increase in total asset and total equity will lead to an increase in market share.

In the beverages firms, the table shows that both total asset and total equity have positive correlation of 0.909 and 0.813 respectively with market share. This is significant at $5 \%$. The implication of this is that an increase in both total asset and total equity will lead to an increase in market share. However, there is strong relationship between total asset, total equity and market share of beverages firms than that of food firms. Conclusively, based on the above, the null hypothesis is hereby rejected and the implication of this is that, there is significant relationship between capitalisation and market power among the sampled firms.

Table 4.1: Correlation Result Showing the Relationship between Capitalisation and Market Power

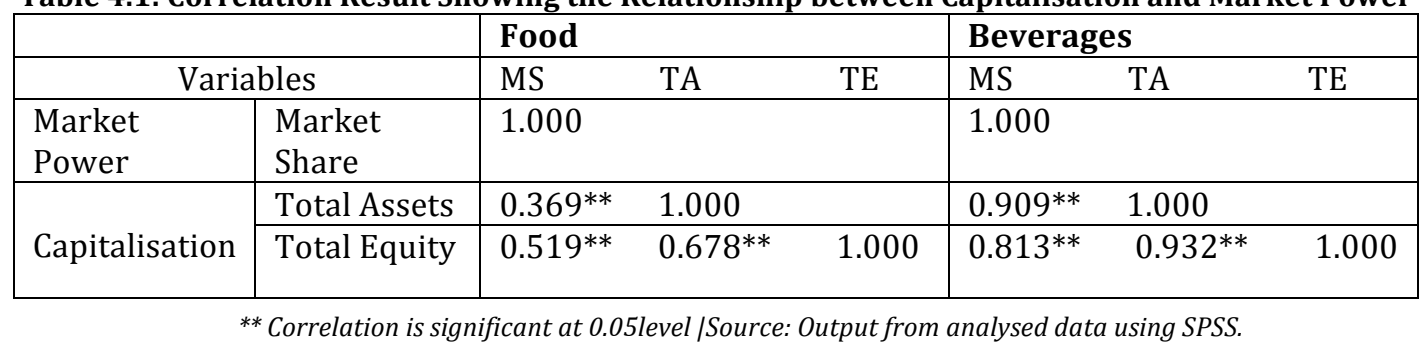

H0: Market power has no significant effect on corporate profitability.

Table 4.2 shows the empirical fixed effects regression results for market power on corporate profitability. The variables involved are market share, sales turnover and return on equity.

Table 4.2 shows that both market share and sales turnover has negative relationship with return on equity as regards the food firms. Both have significant effect on return on equity at $5 \%$ level. A 5\% significant level is used for the tests. The results of the regression model provide goodness of fit with the number of R2 at 56.1\%. R2 represents the proportion of variation of the dependent variable, accounted for by the independent variables the strong predictability of a regression model. This model has f-value for food firms at 6.43.

In the case of beverages firms, both market share and sales turnover have positive relationship with return on equity which is significant at $5 \%$ and $1 \%$ for the t-test respectively. The results of the regression model provide goodness of fit with the number of R2 at 70.5\%. R2 represents the proportion of variation of the dependent variable, accounted for by the independent variables in the regression model. The high $\mathrm{R} 2$ value indicates the strong predictability of a regression model. This model has f-value for beverages firms at 12.34. As a result of this, we reject the null hypothesis which implies that market power has significant effect on corporate profitability.

Table 4.2: Fixed Effects Regression Results of Market Power Effects on Corporate Profitability

\begin{tabular}{|l|l|l|l|l|l|l|l|}
\hline \multicolumn{2}{|c|}{$\begin{array}{c}\text { Variables } \\
\text { (ROE) }\end{array}$} & \multicolumn{3}{c|}{ Food Firms } & \multicolumn{3}{c|}{ Beverages Firms } \\
\cline { 2 - 8 } & Coefficient & t-value & p-value & Coefficient & t -value & p - value \\
\hline \multicolumn{2}{|c|}{ Constant } & 3.834 & 1.05 & 0.302 & 4.674 & 2.48 & 0.131 \\
\hline \multirow{3}{*}{$\begin{array}{l}\text { Market } \\
\text { Power }\end{array}$} & $\begin{array}{l}\text { Market } \\
\text { Share }\end{array}$ & -7.816 & -2.21 & $0.036^{* *}$ & 2.389 & 2.15 & $0.031^{* *}$ \\
\cline { 2 - 8 } & $\begin{array}{l}\text { Sales } \\
\text { Turnover }\end{array}$ & -0.183 & -2.61 & $0.015^{* *}$ & 2.480 & 9.56 & $0.000^{*}$ \\
\hline Goodness of Fit: & & & & & & \\
\hline $\mathrm{R}$ & 0.749 & & & & \\
\hline $\mathrm{R}^{2}$ & 0.561 & & 0.840 & & \\
\hline f-value & 6.43 & & 0.705 & \\
\hline
\end{tabular}

*Significant at 0.01 level; **Significant at 0.05 level /Source: Output from analysed data using SPSS.

H0: Capitalisation size has no significant influence on corporate profitability.

Table 4.3 shows the empirical fixed effects regression results for capitalisation on corporate 
profitability. The variables involved are total asset, total equity and return on equity. Table 4.3 shows that total asset has a positive relationship with return on equity while total equity has a negative relationship with return on equity. However, both are significant at $1 \%$ level.

The results of the regression model provide goodness of fit with the number of R2 at 88.5\%. The high $\mathrm{R} 2$ value indicates the strong predictability of a regression model. This model has $\mathrm{f}-$ value for food firms at $95.97 \%$. As regards the beverages firms, total asset has positive relationship with return on equity while total equity has negative relationship with return on equity. However, the two are significant at $1 \%$ level. The results of the regression model provide goodness of fit with the number of R2 at $64.3 \%$. The high R2 value indicates the strong predictability of a regression model. This model has f-value for beverages at 22.48. Based on this, we reject the null hypothesis. The implication of this is that, capitalisation size has significant influence on corporate profitability.

Table 4.3: Fixed Effects Regression Results of Capitalisation Effects on Corporate Profitability

\begin{tabular}{|c|c|c|c|c|c|c|c|}
\hline \multirow{2}{*}{\multicolumn{2}{|c|}{$\begin{array}{c}\text { Variables } \\
\text { (ROE) }\end{array}$}} & \multicolumn{3}{|c|}{ Food Firms } & \multicolumn{3}{|c|}{ Beverages Firms } \\
\hline & & Coefficient & $\mathrm{t}$-value & $\mathrm{p}$ - value & Coefficient & t-value & $\mathrm{p}$ - value \\
\hline \multicolumn{2}{|c|}{ Constant } & 6.518 & 7.00 & $0.000^{*}$ & 2.480 & 5.16 & $0.000^{*}$ \\
\hline \multirow{2}{*}{$\begin{array}{c}\text { Capitalisatio } \\
\mathrm{n}\end{array}$} & $\begin{array}{l}\text { Total } \\
\text { Asset }\end{array}$ & 2.599 & 8.92 & $0.000^{*}$ & 0.848 & 4.52 & $0.000^{*}$ \\
\hline & $\begin{array}{l}\text { Total } \\
\text { Equity }\end{array}$ & -4.333 & -13.79 & $0.000^{*}$ & -1.158 & -6.29 & $0.000^{*}$ \\
\hline \multicolumn{2}{|c|}{ Goodness of Fit: } & \multirow{4}{*}{\multicolumn{3}{|c|}{$\begin{array}{l}0.941 \\
0.885 \\
95.97\end{array}$}} & \multirow{4}{*}{\multicolumn{3}{|c|}{$\begin{array}{l}0.802 \\
0.643 \\
22.48\end{array}$}} \\
\hline $\mathrm{R}$ & & & & & & & \\
\hline $\mathrm{R}^{2}$ & & & & & & & \\
\hline$f-$ val & & & & & & & \\
\hline
\end{tabular}

*Significant at 0.01 level; **Significant at 0.05 level |Source: Output from analysed data using SPSS.

\section{CONCLUSION AND RECOMMENDATIONS}

The study examined the interrelationship of capitalisation, market power and profitability. Findings from the study revealed that capitalisation and market power have positive significance relationship. This indicates a very strong relationship between the two variables. The study further revealed that market share is an important determinant of profitability. This was to show the important and significant effect of it (market share) on corporate profitability. Overall, the result support that market power has significant effect on the corporate profitability of the sampled firms. Also, the study revealed that capitalisation has greater influence on corporate profitability and this influence is significant. The study based on theoretical expectation, it provides evidence of a positive and significant interrelationship of capitalisation, market power and return on equity measure of profitability of the sampled firms. The implication of this is that, the sampled firms were able to utilize their capitalisation size and market share to impact positively on their firms' profitability.

Based on the findings in the study objectives, the research findings suggest that management can do the following in order to make their companies to be more profitable.

Management must see to an increase in total asset and total equity that will lead to an increase in market share and providing positive return on equity for an organisation.

Management of an organisation need to increase their market share and sales turnover to effectively increase their profitability measure.

Also, total asset as direct effect on return on equity, which is an increase in the total asset will lead to an increase in the profitability measure of the organisation. 


\section{References}

Adebola, S. A. (2002): “An empirical study of a manufacturing firm’s capital structure: the 7up bottlingcompany experience." Babcock Journal of Management and Social Sciences, 1(1), pp 1-15.

Annual Report of Selected Firms (Guinness Nigeria Plc., Nigerian Brewery Plc., International Brewery Plc., Nestle Nigeria Plc., Cadbury Nigeria Plc, and Flour Mills Nigeria Plc.) 2001-2010.

Boodho, R (2009): “Capital Structure and Ownership Structure: a review of literature.” The Journal of on line Education, January Edition, pp 1-8.

Buzzel, R.D., Gale, B.T. and Sultan R.G.M. (2000) Market Share-a key to Profitability. Harvard Business Review, January-February, p97-106.

Fraering, J.M. and Minor, M. S. (2004) the industry-specific Basis of Market Share-Profitability. Journal of Marketing 11(1), 27-37.

Ghosh, A. (2004) Increasing Market share as a Rationable for Corporate Acquisitions. Journal of Business Finance \& Accounting, 31(1) \& (2).

Ghosh, A. (2001) Does operating performance really improve following corporate acquisitions? Journal of Corporate Finance 7p. 151-178.

Hagigi, M., Manzon, G.I. and Mascarenhas, B. (1999) increase assets efficiency to gain multinational market share. Management international Review, 39(3), 205. 